\title{
あと施工アンカーと円柱状シアキーを併用した場合の 接合面の応力状態を考慮した力学モデルの提案
}

円柱状シアキーを用いた間接接合部に関する研究

\author{
PROPOSAL OF MECHANICAL MODEL CONSIDERING STRESS FIELD OF JOINT SURFACE \\ IN THE CASE OF COMBINED USE OF POST-INSTALLED ANCHOR AND CYLINDRICAL SHEAR-KEY \\ Study on indirect joints with cylindrical shear-key
}

\author{
阿部隆 英*1, 坂本啓太 ${ }^{* 2}$, 樋渡 健*3, 高瀬 裕 也*4, 香 取 慶一*5 \\ Takahide ABE, Keita SAKAMOTO, Takeshi HIWATASHI, \\ Yuya TAKASE and Keiichi KATORI
}

\begin{abstract}
When a post-installed anchor and a cylindrical shear-key are used in combination, the stress state of the joint becomes extremely complex. In this study, we performed shearing tests using this combination and analyzed the results, focusing on the axial stresses at the joints. A mechanical model of the combination, considering the axial stresses at the joints, was used to predict the experimental results with high.
\end{abstract}

Keywords : Concrete roughening, Bearing resistance, Seismic retrofitting, Post-installed anchor, Shear-key, Mechanical model 目荒らし，支圧抵抗，而震補強，あと施工アンカー，シアキー，力学モデル

\section{1. はじめに}

既存構造物の耐震補強における，枠付き鉄骨ブレースや制震ブレ 一ス等の補強部材と既存躯体を接合する既存躯体側の接合面には, チッピングによる目荒らし（以下，単に目荒らしと称する）と接着 系あと施エアンカー（以下，あと施エアンカーと略称する）が用い られることが多い。また, 補強部材と既存躯体はグラウトや割裂防 止筋などから構成される間接接合部を介して接合されることが多く, その既存躯体側のせん断耐力式 ${ }^{11}$ は, 一般的にあと施工アンカーに 関する諸元により構成されており，目荒らしによる効果は反映され ていない。しかしながら，目荒らしによる噛み合い抵抗や支圧抵抗 は剛性が高い例えば2) 上に, 更にせん断力を負担することができる。そ のため, 両者を組み合わせた場合の力学挙動を精度良く再現できる 力学モデルがあれば, 接合面のせん断変位を制御して設計すること ができることや, あと施工アンカーと目荒らしによるせん断力の負 担割合を設定できることで, 設計の幅が広がると期待される。また, 目荒らしの力学挙動を適切に評価できれば，設計時に接合面のせん 断変位を小さく制御でき, 補強部材と既存躯体の一体性を高めるこ とが可能となる。
著者らは施工環境に配慮し, 目荒らしに代わる接合技術として, 円柱状シアキー例えば 3)を提案している。この工法では, コアドリルを 用いて既存躯体に凹型の形状を形成させるため，振動，騒音及び粉 塵の発生を目荒らしと比較して大きく低減できる特徵がある。更に 凹部の形状が施工者の技量によらず均等化されるため，せん断耐力 の定量評価が可能である。また，この円柱状シアキーを目荒らしに 代わって接合面に使用した場合は，前述の通り，目荒らしの場合と 同様にあと施工アンカーと併用することで，接合面のせん断変位を 抑えつつ，せん断耐力を大きくすることも期待できる。

著者らは円柱状シアキーの支圧抵抗と, あと施工アンカーのダウ エル抵抗をそれぞれ単独で用いた場合（以下，単独時と称寸る）の

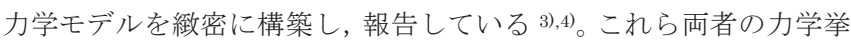
動は大きく異なるため，両者を併用した場合（以下，併用時と呼称 する）の実験結果を, 各々の単独時の力学モデルを累加したモデル で，評価可能か検証する必要がある。プレキャスト接合部の併用に 関する既往の研究では，コッターによる支圧抵抗と接合筋によるダ ウエル抵抗以外に, 中野ら 5) は接合面の摩擦抵抗や付着抵抗を加味 し, 望月ら 6)は接合面に生じる垂直圧縮応力によるせん断摩擦効果

\footnotetext{
*1 飛島建設耐震ソリューション部 主任

*2 飛島建設耐震ソリューション部 主任・修士(工学)

*3 東亜建設工業技術研究開発センター 主任研究員・博士 (工学)

*4 室蘭工業大学大学院もの創造系領域＼cjkstart准教授・博士(工学)

*5 東洋大学理工学部建築学科 教授・博士 (工学)
}

Chief, Seismic Solution Dept., TOBISHIMA Corporation

Chief, Seismic Solution Dept., TOBISHIMA Corporation, M.Eng.

Senior Researcher, Research and Development Center, TOA Corporation, Dr.Eng. Assoc. Prof., College of Design and Manufacturing Technology, Muroran Institute of Technology, Dr.Eng.

Prof., Dept. of Architecture, Fac. of Sci. \& Eng., Toyo University, Dr.Eng. 
を付加した例がある。これらの研究は, 併用時における接合面の圧 縮応力等の軸応力について着目しており, 力学挙動を検証する上で 非常に有用であるが, せん断耐力の評価に主眼を置いていることや, コッターの力学モデルが設計で適用し易いように簡易的なバイリニ ア型とされているなど, 直接本研究で対象とする接合面に応用でき るとは限らない。

そこで本論文では, まず円柱状シアキーとあと施エアンカーを併 用した場合のせん断実験を行い, あと施工アンカーと円柱状シアキ 一それぞれの単独時のモデルを単純に累加した力学モデル（以下， 修正前モデルと称する）と実験結果を比較する。その後, 実験結果 から接合面の軸応力による応力状態及び力学挙動を推定し, これら の影響を反映した併用時の力学モデル (以下, 修正モデルと称する) を提案することを目的とする。また，本論文が対象とする部位は， グラウトを用いる間接接合部において, せん断変形が顕著に生じる 既存躯体側の接合面であり, 提案する力学モデルは, 圧縮応力下で せん断応力が作用する場合とする。

2. 円柱状シアキー及びあと施エアンカーの想定するカ学挙動 本章では，著者らが想定している円柱状シアキー及びあと施工ア ンカーそれぞれのせん断抵抗機構と力学挙動の概念について述心゙, それぞれの詳細な力学モデルと算定式については 4 章にて記載する。

Fig.1 に想定する接合部のせん断抵抗要素と力学挙動の概念を示 す。同図(a)に示すように, 接合面のせん断抵抗要素は円柱状シアキ 一による支圧抵抗, あと施工アンカーによるダウエル効果, 更に接 合面の摩擦抵抗や付着抵抗が考えられる。ここで本実験では, 接合 面に生じる摩擦抵抗や付着抵抗を極力小さく寸るために, 円柱状シ アキー以外の部位にグリスを塗布していることや，後述するが接合 面のせん断変位 $\delta_{H}$ の増大に伴い, 既存部コンクリートと補強部グラ ウトが離間する現象が生じることから，本論文では支圧抵抗とダウ エル抵抗のみに着眼して記述する。ただし, 実施工では摩擦抵抗や 付着抵抗により，安全側に寄与することも考えられるが，これらの 影響に関しては, 今後の課題としたい。

ここで著者らが報告した円柱状シアキーの力学挙動について簡略 化して述べる。Fig.1(b)に示すように, 円柱状シアキーの力学モデル は，一般的に支圧破壊 7) と称される円柱状シアキー側面でのコンク リートの圧壊と，シアオフ破壊 8) と称される円柱状シアキーの底面 （凸部側に対する底面）におけるせん断破壊の，破壊形式毎に構築 されている ${ }^{3)}$ 。また，1 章でも触れたように補強部材と既存部材の 一体性を高めるため, 外付け補強の接合部の設計を参考に $\delta_{H}$ を $2 \mathrm{~mm}$ 以下に抑える 9 )ことを制限值とする。そこで， $\delta_{H}=2 \mathrm{~mm}$ まで に着目すると, 最大せん断力 $Q_{\max }$ に達する時の $\delta_{H}$ (Fig.1(b)の $\delta_{\max 1}$ に該当する）は $0.2 \mathrm{~mm}$ 程度であり, その後の挙動は概称 $Q_{\max }$ を維 持した後, 荷重低下寸る。この荷重低下が始まるせん断変位を $\delta_{\max 2}$ と定義する。

あと施エアンカーのダウエル抵抗によるカ学モデルは Fig.1(c)に あるように, 弾性支承梁の方程式から反力係数を用いて構築されて いる ${ }^{4)} 。 \delta_{H}=2 \mathrm{~mm}$ まで $\delta_{H}$ の増大に伴い, 徐々に剛性の低下を伴いつ つ，せん断力 $Q$ は緩やかに増加し続ける傾向がある。

以上より, 円柱状シアキーとあと施工アンカーは, それぞれ異な った力学挙動を呈する。しかしながら, これらを併用した場合, 初
期の剛性は円柱状シアキーが寄与することで高くなり, 円柱状シア キーの荷重低下領域では, あと施工アンカーのダウエル効果により, せん断力の低下が抑制されると考えられる。そこで Fig.1(b)，(c)に それぞれ示す円柱状シアキーとあと施工アンカーの力学モデルを単 に累加した修正前モデルを Fig.1(d)に示す。この修正前モデルは, 前述のように $\delta_{H}=0.2 \mathrm{~mm}$ まで高い剛性を有し，その後円柱状シアキ 一の荷重低下量とあと施工アンカーの荷重増大量の絶対值が同程度 で推移するため, $\delta_{H}=0.2 \mathrm{~mm}$ 以降の $Q$ の増減量は小さくなる。本論 文では修正前モデルと実験結果による荷重-変形曲線やせん断耐力 を比較検証することから始める。

\section{3. 実験の概要}

\section{1 実験パラメータ}

実験パラメータ及び材料試験結果を Table 1 に示す。あと施工ア ンカーとして用いた異形鉄筋のアンカー筋のひずみから，単独時と 併用時の接合面の軸応力の比較を行うため, 主なパラメータはあと 施工アンカーのみを配置した試験体（以下，A シリーズと称する）, 及びあと施工アンカーと円柱状シアキーを併用した試験体（以下， AS シリーズと称する）とした。なお，A シリーズの 3 体は文献 4) で扱った試験体と同じものであるが, AS シリーズの 16 体について は，本論文にて初めて扱う試験体である。

あと施工アンカーのダウエル抵抗は, アンカー筋側面の支圧抵抗 であり, 既存部コンクリートの圧縮強度 $C \sigma_{B}$ に依存寸る 4$)$ こから, $\mathrm{A}$ シリーズの変動因子は $c \sigma_{B}$ とした。また, 耐震補強を要する建物 の $c \sigma_{B}$ は, 一般的に $13.5 \sim 30 \mathrm{~N} / \mathrm{mm}^{2}$ 程度であるため, 概ねこの範 囲で 3 水準を目標として打設した。アンカー筋の径と鋼種は，それ ぞれ耐震補強で多く使用される D 16 及び SD 345 とした。接合面の 平均圧縮応力度 $\sigma_{0}$ においては, 内付け補強工法の接合部にシアキー

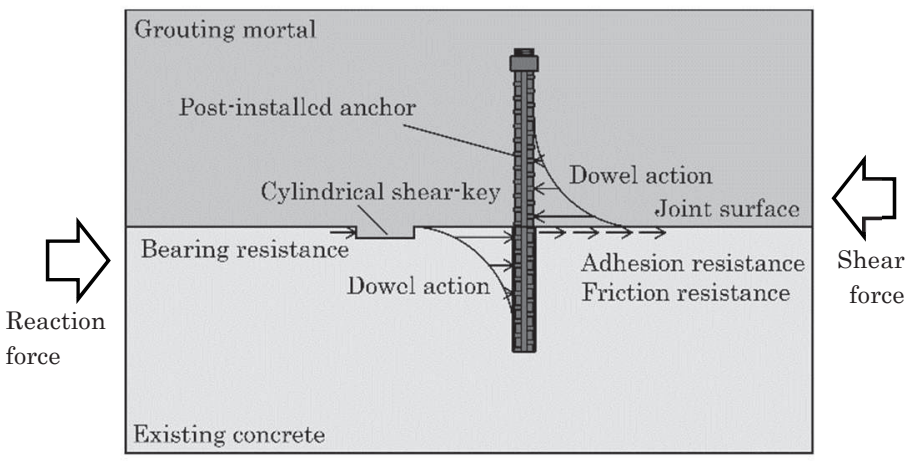

(a) Image of shear resistance elements

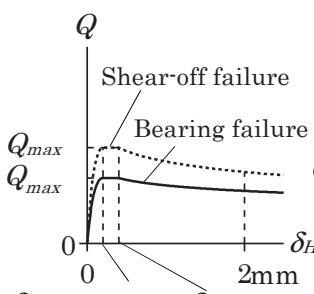

$\delta_{\max 1}=0.2 \mathrm{~mm} \delta_{\max 2}$

(b) Mechanical model of cylindrical shear-key

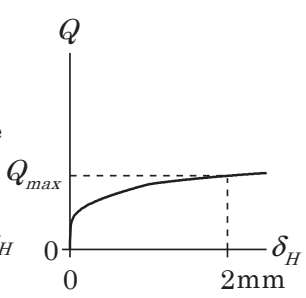

(c) Mechanical model of post-installed anchor

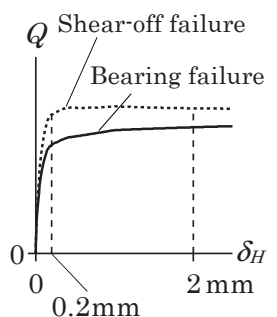

(d) Pre-modified mode 1
Fig. 1 Concept of shear resistance elements and mechanical behavior of joint surface 
Table 1 Test parameters and material test results

\begin{tabular}{|c|c|c|c|c|c|c|c|c|c|c|c|}
\hline \multirow{2}{*}{ 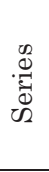 } & \multirow{2}{*}{ No. } & \multirow{2}{*}{$\begin{array}{c}\sigma_{0} \\
\left(\mathrm{~N} / \mathrm{mm}^{2}\right)\end{array}$} & \multicolumn{2}{|c|}{ Existing concrete } & \multicolumn{2}{|c|}{ Grouting mortal } & \multicolumn{2}{|c|}{$\begin{array}{c}\text { Cylindrical } \\
\text { shear-key }\end{array}$} & \multicolumn{3}{|c|}{ Anchor bolt } \\
\hline & & & $\begin{array}{c}C \sigma_{B} \\
\left(\mathrm{~N} / \mathrm{mm}^{2}\right)\end{array}$ & $\begin{array}{c}E_{C} \\
\left(\mathrm{kN} / \mathrm{mm}^{2}\right)\end{array}$ & $\begin{array}{c}{ }_{G} \sigma_{B} \\
\left(\mathrm{~N} / \mathrm{mm}^{2}\right)\end{array}$ & $\begin{array}{c}E_{G} \\
\left(\mathrm{kN} / \mathrm{mm}^{2}\right)\end{array}$ & $\begin{array}{c}R \\
(\mathrm{~mm})\end{array}$ & $R / t$ & $d_{a}$ & $\begin{array}{c}\sigma_{y} \\
\left(\mathrm{~N} / \mathrm{mm}^{2}\right)\end{array}$ & $\begin{array}{c}E_{S} \\
\left(\mathrm{kN} / \mathrm{mm}^{2}\right)\end{array}$ \\
\hline \multirow{3}{*}{ A } & A16-LL1 & \multirow{3}{*}{0.48} & 14.5 & 22.1 & 57.3 & 24.8 & \multirow{3}{*}{ - } & & \multirow{3}{*}{ D16 } & 379 & 181 \\
\hline & A16-LM1 & & 17.8 & 25.7 & 69.4 & 25.7 & & & & 381 & 189 \\
\hline & A16-LH1 & & 29.9 & 26.3 & 57.3 & 26.7 & & & & 369 & 196 \\
\hline \multirow{10}{*}{$\begin{array}{l}\mathrm{A} \\
\mathrm{S}\end{array}$} & A16S52-5LL1,2 & \multirow{3}{*}{0.48} & 14.5 & 22.1 & 57.3 & 25.8 & \multirow{5}{*}{52} & \multirow{5}{*}{5.2} & \multirow{5}{*}{ D16 } & \multirow{10}{*}{379} & \multirow{10}{*}{181} \\
\hline & A16S52-5LM1 & & 21.7 & 26.5 & 56.6 & 26.7 & & & & & \\
\hline & A16S52-5LH1,2 & & 32.9 & 27.7 & 57.3 & 25.8 & & & & & \\
\hline & A16S52-5ML1,2 & 0.95 & 14.5 & 22.1 & 57.3 & 25.8 & & & & & \\
\hline & A16S52-5MM1 & 0.95 & 21.7 & 26.5 & 56.6 & 26.7 & & & & & \\
\hline & A16S52-10LL1,2 & \multirow{3}{*}{0.48} & 14.5 & 22.1 & 57.3 & 25.8 & \multirow{5}{*}{52} & \multirow{5}{*}{10.4} & \multirow{5}{*}{ D16 } & & \\
\hline & A16S52-10LM1 & & 21.7 & 26.5 & 56.6 & 26.7 & & & & & \\
\hline & A16S52-10LH1,2 & & 32.9 & 27.7 & 57.3 & 25.8 & & & & & \\
\hline & A16S52-10ML1,2 & \multirow{2}{*}{0.95} & 14.5 & 22.1 & 57.3 & 25.8 & & & & & \\
\hline & A16S52-10MM1 & & 21.7 & 26.5 & 56.6 & 26.7 & & & & & \\
\hline
\end{tabular}

${ }_{C} \sigma_{B}$ :Concrete compressive strength, $E_{C}$ :Concrete elastic modulus, ${ }_{G} \sigma_{B}$ :Grouting mortal compressive strength, $E_{G}:$ Grouting mortal elastic modulus, $R$ :Diameter of cylindrical shear-key, $R / t$ :Width to height ratio, $\sigma_{y}$ :Anchor bolt yield strength, $E_{S}$ :Anchor bolt elastic modulus, $d_{a}:$ Diameter of anchor bolt

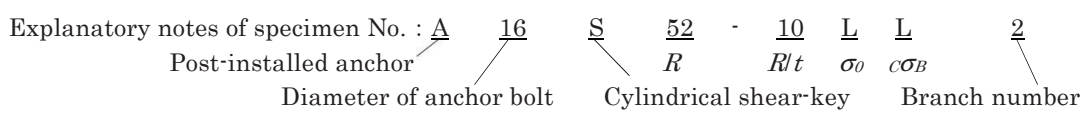

$\sigma_{0} \quad \mathrm{~L}: 0.48 \mathrm{~N} / \mathrm{mm}^{2}, \mathrm{M}: 0.95 \mathrm{~N} / \mathrm{mm}^{2}$

$c \sigma_{B} \quad \mathrm{~L}:$ Low level, $\mathrm{M}$ : Middle level, $\mathrm{H}$ : High level
(この研究 10)では鋼製シアキーが使用されている) が用いられた既 往の研究から，接合面のずれ変形量が $1 \mathrm{~mm}$ 以降の領域おいて，概 祇 $0.4 \mathrm{~N} / \mathrm{mm}^{2}$ で推移寸ると報告されているため, $0.48 \mathrm{~N} / \mathrm{mm}^{2}$ とした。 なお，この接合面の平均圧縮応力度は地震時に鉄骨ブレースや制震 ブレース等の反力として生じるものや， $\delta_{H}$ の増大と共に既存部コン クリートと補強部グラウトに離間 (以下, 目開きと称する) が生じ, その目開きを柱や梁の架構が拘束していることで生じた応力である と考えられる。また, 外付け補強においても, 偏心モーメントによ り接合面には圧縮応力が作用する。本実験で扱うの。は, 次式で示す ように，軸方向力 $N$ を接合面の面積 $A$ で除した值である。

$$
\sigma_{0}=N / A
$$

円柱状シアキーのせん断耐力や力学挙動は $c \sigma_{B}$ 及び $\sigma_{0}$ に依存する 3),11) とから, $\mathrm{AS}$ シリーズの変動因子は $\sigma_{0}$ 及び ${ }_{C} \sigma_{B}$ とした。 $\sigma_{0}$ は力 学挙動を把握しやすいように $0.48 \mathrm{~N} / \mathrm{mm}^{2}$ とその 2 倍である $0.95 \mathrm{~N} / \mathrm{mm}^{2}$ とし， $c \sigma_{B}$ においては $\mathrm{A}$ シリーズと比較できるように $\sigma_{0}=0.48 \mathrm{~N} / \mathrm{mm}^{2}$ の場合で 3 水準, $\sigma_{0}=0.95 \mathrm{~N} / \mathrm{mm}^{2}$ の場合で 2 水準と した。円柱状シアキーの直径 $R$ は，接合部の幅が最小で $200 \mathrm{~mm}$ 程 度であることや，あと施工アンカーのピッチが $150 \mathrm{~mm}$ 程度である ことから, 円柱状シアキーがこの範囲で支圧抵抗できるへりあきと， はしあきを確保できるように $R=52 \mathrm{~mm}$ とした。円柱状シアキーの 破壊形式は, $R$ と円柱状シアキーの高さ $t$ の比である幅高比（以下， $R / t$ と呼称寸る）により異なるため, $R / t$ は支圧破壊を想定した $R / t$ $=10$ とシアオフ破壊を想定した $R / t=5$ の 2 段階とした。なお，ア ンカー筋の径及び鋼種は，A シリーズと同じとした。

\section{2 試験体概要}

試験体の諸元寸法を Fig. 2 に示す。A シリーズでは, あと施工ア ンカーの配列をダブルとし，ピッチを $150 \mathrm{~mm}$, ゲージを $85 \mathrm{~mm}$ と した。また, あと施工アンカーの施工は湿式コアドリルで穿孔した 後, あと施工アンカーの有効埋め込み深さ $L_{e}$ をアンカー筋の直径 $d_{a}$

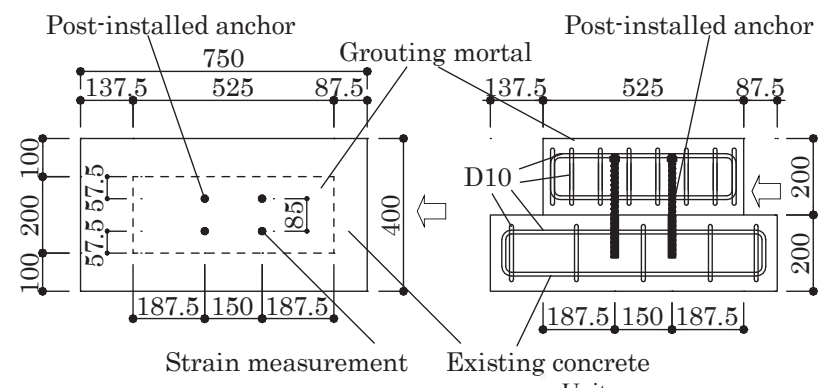

Unit : mm

(a) Series $A \quad \square$ : Force direction Cylidrical shear-key

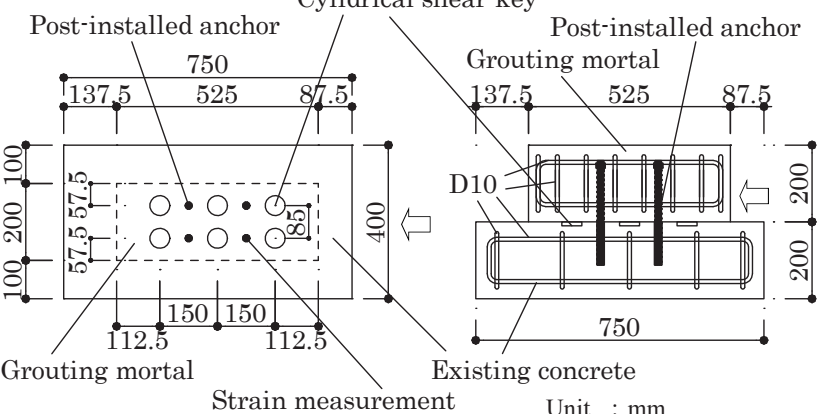

(b) Series AS $\square$ : Force direction

Fig. 2 Dimensions of specimen

の 7 倍 $\left(7 d_{a}\right)$ として, 平先寸切形状のアンカー筋を注入方式カート リッジ型のエポキシ樹脂系接着剂注1),注 2)を用いて定着させた。

$\mathrm{AS}$ シリーズにおいては, 円柱状シアキーのピッチ, ゲージ及び配 列をあと施工アンカーと同じとし, 円柱状シアキーを 6 個配置した。 配置した円柱状シアキーからの補強部のはしあき寸法は, $R=52 \mathrm{~mm}$ の 2 倍以上である $112.5 \mathrm{~mm}$ を確保し, 補強部の破壊形式が確実に 円柱状シアキーのシアオフ破壊となるように配慮した。なお，あと 施エアンカーの位置や仕様は，A シリーズと同じである。

試験体の補強部は，耐震補強に用いる間接接合部を模擬している 
ためグラウトとし, 高さと幅は耐震補強の一般的な断面寸法から両 者共に $200 \mathrm{~mm}$, 割裂防止筋はフープ形状で補強筋比 $0.95 \%$ とした。 また, 既存部コンクリートは既存建物の梁を模擬していることから, 幅は $400 \mathrm{~mm}$ とし, 長さは補強部グラウトの寸法より大きい $750 \mathrm{~mm}$, 高さについては $200 \mathrm{~mm}$ とした。

試験体の施工において 2 章で述べた通り，接合面には既存部コン クリートと補強部グラウトの間に生じる摩擦抵抗や付着抵抗を極力 小さくするために, 円柱状シアキー以外の部位にグリスを塗布した。 また, 既存部コンクリートを脱型し, 試験体を平置きとした状態で, $\mathrm{A}$ シリーズの試験体は下向きの態勢であと施工アンカーを施工し, AS シリーズの試験体においては, 円柱状シアキーを施工した後, A シリーズ同様の態勢であと施工アンカーを施工した。その後, 全試 験体において接合部を想定した補強部グラウト側の型枠を組み, 割 裂防止筋を配置した後, プレミックスタイプのグラウトを打設した。

\section{3 加力方法及び計測方法}

加力装置を Fig. 3 に示す。軸方向は一定の荷重制御とし, 水平方 向は一方向単調載荷とした。加力装置には軸方向の荷重の制御用と して最大荷重 $200 \mathrm{kN}$ のアクチュエーターを使用し, 水平方向の荷 重を制御するために最大荷重 $500 \mathrm{kN}$ の油圧ジャッキを使用した。 同図に示すように, 加力装置による摩擦抵抗を極力小さくするため, 加圧用厚板鋼板には 2 方向のローラー支承を用いている。軸方向力 が試験体全体に均等に分布するように，加圧用厚板鋼板と補強部グ ラウトの間にはゴムシートが敷設されている。

計測計画を Fig.4 に示す。計測は 2 章に記載と同じ「接合面のせ ん断変位 $\delta_{H}$ 」及び既存部コンクリートと補強部グラウトの離間距離 $\delta_{V}$ (以下, 目開き変位と呼称する）とした。また， $\delta_{H}$ 及び $\delta_{V}$ は既存 部コンクリート上に高感度変位計をそれぞれ 2 箇所ずつ配置し, そ の計測した值の平均値を採用した。

ひずみを計測したアンカー筋の位置を Fig.2 に図示し, Fig.5 に ひずみの計測位置を示す。実験結果からアンカー筋の弾性曲げモー メントと弾性軸力が算定できるように, ひずみの計測は加力方向手 前側と奥側とした。また，原則として計測したひずみからアンカー 筋が負担する軸力を算定できるように，鈆直軸力を導入する前の状 態でアンカー筋のひずみを 0 として計測を開始したが, 試験体 A16S52-5LM1,A16S52-5MM1,A16S52-10LM1,A16S52-10MM1 の 4 体については, 軸力導入後にアンカー筋のひずみを 0 として計 測を開始した。なお，全試験体から前述の 4 体を除いた試験体にお ける, Fig. 5 に示す接合面から $0.5 d_{a}$ のアンカー筋のひずみの平均值

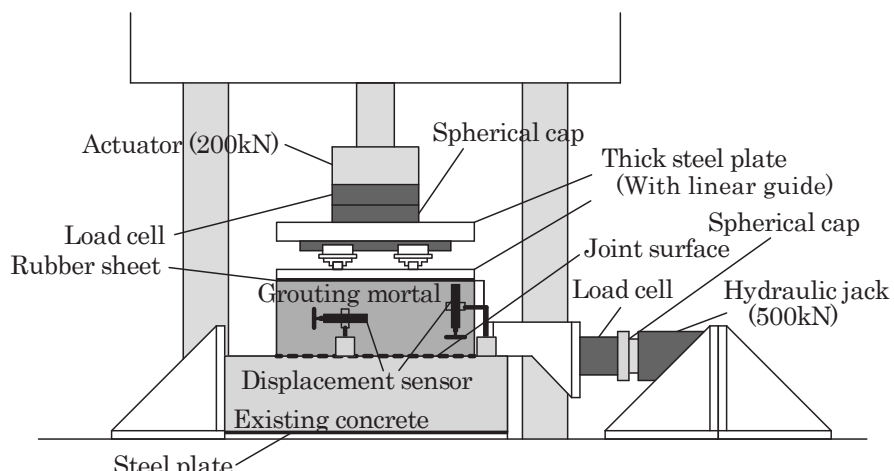

Steel plate

Fig. 3 Loading equipment of shear loading test
は, $-38 \mu \sim-56 \mu$ の範囲であり, 鉛直軸力導入前後によるアンカー筋 への影響は極めて小さいと言える。

\section{4. 接合面の力学挙動}

\section{1 単独時のカ学モデル}

本節では，2 章で述べた円柱状シアキーとあと施工アンカーのそ れぞれ力学モデルを, 算定式と共に記載する。また，著者らが報告 している単独時のあと施工アンカー4)と円柱状シアキー3)の力学モ デルについて, 併用時の力学モデルを構築する際に理解しやすい様, 一部の記号を再定義している。

(1) あと施工アンカー

本項に記載するあと施工アンカーの力学モデルは, 3.2 節で述ベ た接着剂 12), 注 1), 注 2), もしくはこれと同等の性質の接着剂で, 定着長 さを $7 d_{a}$ とした場合に適用可能である。

あと施工アンカー単独時のせん断変位 $\delta_{H}$ 時におけるせん断力 $\delta Q_{a}$ は, 次式で求められる。

$$
{ }_{\delta} Q_{a}=n_{a} \cdot{ }_{\delta} q_{a}
$$

ここに, $n_{a}$ は接合面に配置されたあと施工アンカーの本数, $\delta q_{a}$ は 単独時におけるせん断変位 $\delta_{H}$ 時のあと施工アンカー 1 本が負担す るせん断力であり，次式にて算定される ${ }^{4)}$

$$
{ }_{\delta} q_{a}={ }_{c} \delta_{H} \cdot 2{ }_{c} \beta^{3} \cdot E_{s} \cdot I_{s}={ }_{G} \delta_{H} \cdot 2{ }_{G} \beta^{3} \cdot E_{s} \cdot I_{s}
$$

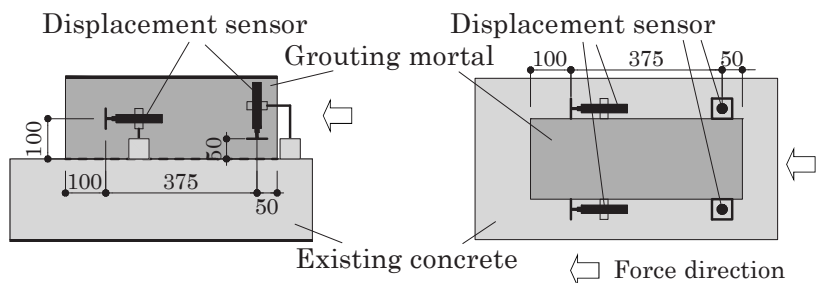

Fig. 4 Measurement plan

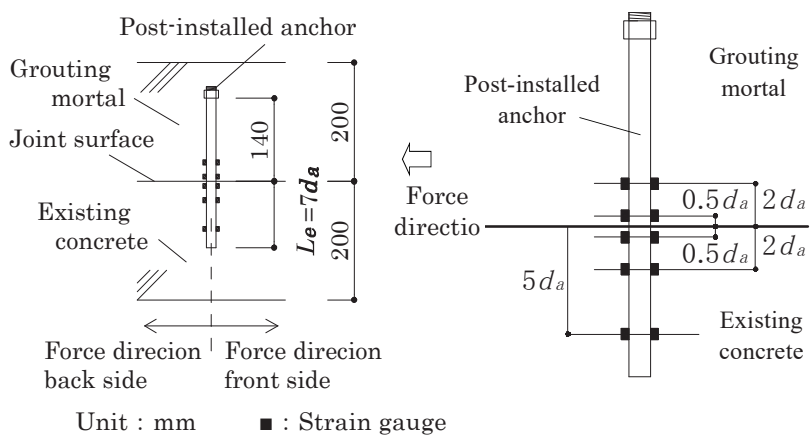

Fig. 5 Strain measurement position

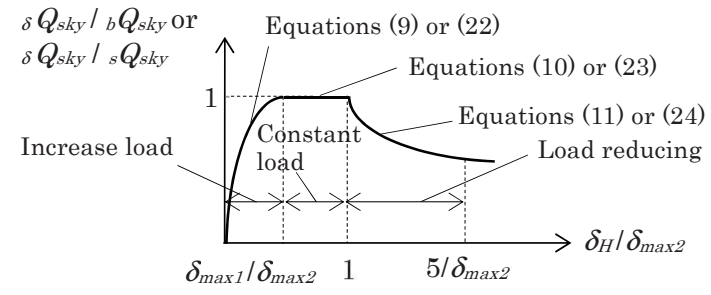

Fig. 6 Application range of equations on mechanical behavior of cylindrical shear-key 


$$
\begin{aligned}
& \delta_{H}={ }_{C} \delta_{H}+{ }_{G} \delta_{H} \\
& \frac{{ }_{C} \delta_{H}}{{ }_{G} \delta_{H}}=\left(\frac{E_{G} \cdot{ }_{G} \sigma_{B}}{E_{C} \cdot{ }_{C} \sigma_{B}}\right)^{\frac{3 n}{4-3 m}} \\
& { }_{i} k_{c}=\alpha \frac{\left(E_{i} \cdot{ }_{i} \sigma_{B}\right)^{n}}{\left(E_{S} \cdot{ }_{i} \delta_{H}\right)^{m}} \\
& \alpha=B \cdot \delta_{H}^{C} \\
& { }_{i} \beta=\sqrt[4]{\frac{{ }_{i} k_{C} \cdot d_{a}}{4 E_{S} \cdot I_{S}}}
\end{aligned}
$$

ここに $E_{S}, I_{S}$ はそれぞれアンカー筋のヤング係数, 断面二次モー メント， $E_{C}$ は既存部コンクリートのヤング係数， $E_{G}$ は補強部グラ ウトのヤング係数， $k_{c}$ は反力係数， $\alpha$ は $k_{c}$ による非線形性を表現す るための関数, $n(=0.343), m(=3 / 4), B(=23595)$ 及び $C(=-0.350)$ は係数である。また, $E, k_{c}, \sigma_{B}, \delta_{H}$ 及び $\beta$ の下付きの $i$ は, 既存部 コンクリートもしくは補強部グラウトのいずれかを示し,$i=C$ は既 存部コンクリート， $i=G$ は補強部グラウトである。

(2) 円柱状シアキー

Fig.1(b)に示す円柱状シアキーを単独で用いた場合の力学挙動は Fig.6 に示寸力学モデルで表現され 3), 力学モデルは荷重漸増領域, 荷重一定領域及び荷重低下領域の 3 領域で構成される。Fig.6 に円 柱状シアキーの力学モデルにおける式の範囲を示し, 適用寸る式番 号を併記する。各領域における, 円柱状シアキー単独時の支圧破壊 型のせん断変位 $\delta_{H}$ 時におけるせん断力 $\delta Q_{s k y}$ は, 次式による。

$$
\begin{array}{ll}
\frac{{ }_{\delta} Q_{s k y}}{{ }_{b} Q_{s k y}}=6.75\left(e^{-0.812\left(\frac{\delta_{H}}{\delta_{\max 1}}\right)}-\right. & \left.e^{-1.218\left(\frac{\delta_{H}}{\delta_{\max 1}}\right)}\right) \\
\frac{{ }_{\delta} Q_{s k y}}{{ }_{b} Q_{s k y}}=1 & \left(0 \leq \delta_{H} / \delta_{\max 2} \leq \delta_{\max 1} / \delta_{\max 2}\right) \\
\frac{{ }_{\delta} Q_{s k y}}{{ }_{b} Q_{s k y}}={ }_{b} \gamma \cdot \ln \left(\delta_{H} / \delta_{\max 2}\right)+1 & \left(1 \leq \delta_{H} / \delta_{\max 2} \leq 5 / \delta_{\max 2} \leq \delta_{H} / \delta_{\max 2} \leq 1\right)
\end{array}
$$

ここに, ${ }_{b} Q_{s k y}$ は支圧破壊型の円柱状シアキーのせん断耐力, $\delta_{\max 1}$ は ${ }_{b} Q_{s k y}$ に達した時の $\delta_{H}, \delta_{\max 2}$ は荷重一定領域の最終時の $\delta_{H}$ である。 なお， $\delta_{\max 1}$ は文献 3$)$ において $0.2 \mathrm{~mm}$ としているが，修正モデルに おいてこの值を変動できるように, 変数とした。また, ${ }^{2} \gamma$ は支圧破 壊型の荷重低下領域における $\delta Q_{s k y}$ の低下を表現する関数であり, $\delta_{\max 2}$ 及び ${ }_{b} \gamma$ は下記に示寸通りである。

$$
\begin{aligned}
& \delta_{\max 2}=0.42 \sigma_{0} \\
& { }_{b} \gamma={ }_{b} A \cdot \ln \left(\sigma_{0}^{\prime}\right)+{ }_{b} B \\
& \sigma_{0}^{\prime}=N /{ }_{p} A_{\text {sky }}
\end{aligned}
$$

ここに, ${ }_{b} A(=0.052)$ 及び ${ }_{b} B(=-0.229)$ は係数, ${ }_{p} A_{s k y}$ は配置された 円柱状シアキー全数の水平投影面積, $\sigma_{o}^{\prime}$ は円柱状シアキーに生じる 平均圧縮応力度である。

下記に示すように， ${ }^{2} Q_{s k y}$ は式(15)により支圧破壊型の円柱状シア キーの 1 個当たりのせん断耐力 ${ }_{b} q_{s k y}$ に, 接合面に配置された円柱状 シアキーの個数 $n_{s k y}$ を乗じて算定され， ${ }_{b} q_{s k y}$ は式(16)〜 (21)により 算定される。

$$
\begin{aligned}
& { }_{b} Q_{s k y}=n_{s k y} \cdot{ }_{b} q_{s k y} \\
& { }_{b} q_{s k y}=A_{s k y} \cdot \sigma_{c s} \\
& A_{s k y}=\frac{\pi \cdot R \cdot t}{2} \\
& \sigma_{c s}=C_{C} \cdot C_{N} \cdot C_{R} \cdot \bar{\sigma}_{c s}
\end{aligned}
$$

$$
\begin{array}{rrr}
C_{C}=\frac{0.552{ }_{C} \sigma_{B}+44.2}{56.0} & \left(10.3 \leq{ }_{{ }_{C} \sigma_{B}} \leq 32.9 \mathrm{~N} / \mathrm{mm}^{2}\right) \\
C_{N}=\frac{39.1 \sigma_{0}+34.8}{71.9} & \left(0.48 \leq \sigma_{0} \leq 1.43 \mathrm{~N} / \mathrm{mm}^{2}\right) \\
C_{R}=\frac{-1.32 R+123}{56.0} & (40 \leq R \leq 60 \mathrm{~mm})
\end{array}
$$

ここに, $A_{s k y}$ は受圧面積, $\sigma_{c s}$ は ${ }_{b} q_{s k y}$ 時の平均支圧応力度 $\sigma_{c}$ のせ 几断方向成分, $C_{C}, C_{N}, C_{R}$ は $\sigma_{c s}$ に対寸る $c \sigma_{B}, \sigma_{0}, R$ それぞれの 補正係数, $\bar{\sigma}_{c s}\left(=75.3 \mathrm{~N} / \mathrm{mm}^{2}\right)$ は平均支圧応力度である。

シアオフ破壊型の場合の $\delta Q_{s k y}$ は，次式により算定される。

$$
\begin{aligned}
& \begin{array}{r}
\frac{{ }_{\delta_{S}} Q_{S k y}}{{ }_{s} Q_{S k y}}=6.75\left(e^{-0.812\left(\frac{\delta_{H}}{\delta_{\max 1}}\right)}-e^{-1.218\left(\frac{\delta_{H}}{\delta_{\max 1}}\right)}\right) \\
\left(0 \leq \delta_{H} / \delta_{\max 2} \leq \delta_{\max }\right.
\end{array} \\
& \frac{{ }_{\delta} Q_{s k y}}{{ }_{s} Q_{s k y}}=1 \quad\left(\delta_{\max 1} / \delta_{\max 2} \leq \delta_{H} / \delta_{\max 2} \leq 1\right) \\
& \frac{{ }_{\delta} Q_{s k y}}{{ }_{s} Q_{s k y}}={ }_{s} \gamma \cdot \ln \left(\delta_{H} / \delta_{\max 2}\right)+1\left(1 \leq \delta_{H} / \delta_{\max 2} \leq 5 / \delta_{\max 2}\right) \\
& { }_{s} \gamma={ }_{s} A \cdot \ln \left(\sigma_{0}^{\prime}\right)+{ }_{s} B
\end{aligned}
$$

ここに, ${ }_{s} \gamma$ はシアオフ破壊型の荷重低下領域における $\delta Q_{s k y}$ の低下 を表現する関数, ${ }_{s} A(=0.054)$ 及び ${ }_{s} B(=-0.268)$ は係数である。また， シアオフ破壊型のせん断耐力 ${ }_{s} Q_{s k y}$ は，次式にて算定される。

$$
\begin{aligned}
& { }_{s} Q_{s k y}=n_{s k y} \cdot{ }_{s} q_{s k y} \\
& { }_{s} q_{s k y}=\left(0.24{ }_{G} \sigma_{B}+0.68 \sigma_{0}^{\prime}\right){ }_{p} A_{s k y} / n_{s k y}
\end{aligned}
$$

ここに，sqsky はシアオフ破壊型の円柱状シアキーの 1 個当たりの せん断耐力である。

\section{2 併用時の力学挙動に関する考察}

本節では，前節で述べた円柱状シアキーとあと施工アンカーそれ ぞれ単独で用いた場合の力学モデルを, 単に累加した修正前モデル と実験值を比較する。修正前モデルのせん断力 $\delta Q$ は次式となる。

$$
{ }_{\delta} Q={ }_{\delta} Q_{a}+{ }_{\delta} Q_{s k y}
$$

Fig.7 に修正前モデルによる $Q-\delta_{H}$ 関係の一例を示す。同図を観

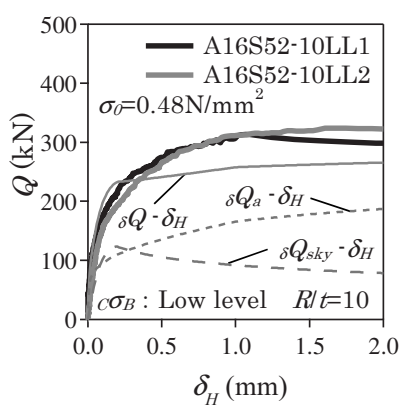

(a) A16S52-10LL1, 2

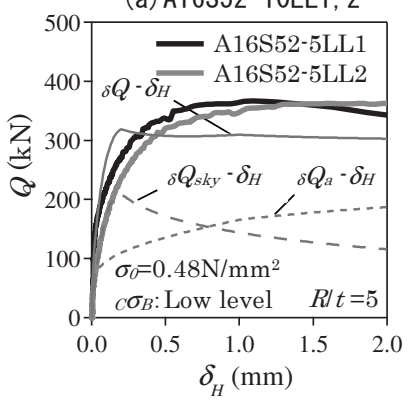

(c) A16S52-5LL1, 2

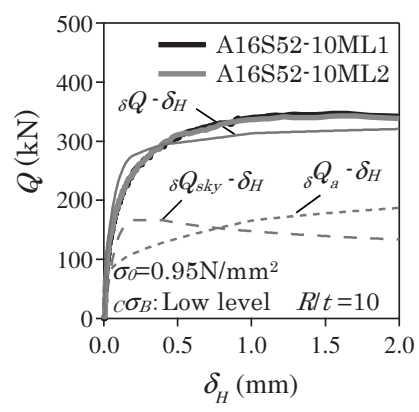

(b) A16S52-10ML1, 2

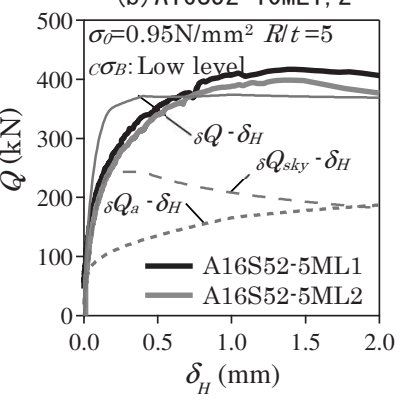

(d) A16S52-5ML1, 2

Fig. 7 Example of $Q-\delta_{H}$ relations of pre-modified model 
察すると, 概ね $\delta_{H}$ が $0.2 \mathrm{~mm}$ 以下の範囲において, 修正前モデルは 実験值より剛性が高く, $Q$ が大きく評価され, それ以降の $\delta_{H}$ におい ては, 修正前モデルが実験值より小さい值を推移している。また, 円柱状シアキー単独の $\delta Q_{s k y}-\delta_{H}$ 関係は, $\delta_{\max 1}=0.2 \mathrm{~mm}$ で最大せん断

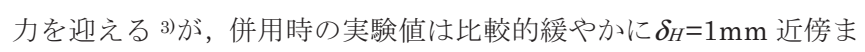
で， $Q$ が漸増している。

Fig. 8 に $\delta_{V}-\delta_{H}$ 関係を示す。A シリーズの $\delta_{V}$ は $\delta_{H}$ の $1 / 10$ 程度であ るが, AS シリーズの $\delta_{V}$ は概ね $\delta_{H}$ の $1 / 2$ から同程度の範囲を推移し ている。ここで, 仲地ら ${ }^{13)}$ の研究を見ると, コッターを用いたプレ キャストの接合部でも, 目開きは圧縮及び引張領域に関わらず接合 面の全領域で生じている。このことから, 本実験においても円柱状 シアキーにより，目開きは大きく推移したと考えられる。

Fig.9 に想定する破壊形式毎の挙動を示す。同図に示すように支 圧破壞型の円柱状シアキーは, せん断変位の増大により円柱状シア キーの側面が損傷し, その損傷面を乗り越えるような挙動を呈する ことから, $\delta_{V}$ が増大寸ると思われる。また, シアオフ破壊型の円柱 状シアキーについては, シアオフ破壞後, 破壊面の凹凸による噛み 合い抵抗が生じることからせん断変位の増大に伴い $\delta_{V}$ も増大寸る と考えられる。つまり, 併用時の $\delta_{V}$ は試験体により差異が見られる ものの, 両者の破壊形式共に円柱状シアキーの影響で増大寸ること がわかる。これらのことから， $\delta_{V}$ が大きい $\mathrm{AS}$ シリーズのアンカー 筋には, A シリーズより大きな引張力が生じていると考えられる。 ここで高瀬ら ${ }^{14), 15)}$ は, アンカー筋に引張力を生じさせた状態でせん 断実験を実施した結果, アンカー筋に生じる引張力が大きい程, せ ん断力が小さくなる現象を定量化して報告している。これらの傾向 を踏まえると, 併用時におけるあと施工アンカーが負担するせん断 力 $C_{\delta} Q_{a}$ は, 単独時の $\delta Q_{a}$ より小さくなると推察される。

以上の傾向を整理すると, 計算值 $\delta Q$ は実験值より小さく, $C_{\delta} Q_{a}$ も ${ }_{\delta} Q_{a}$ より小さくなることから, 併用時における円柱状シアキーが負 担するせん断力 $C_{\delta} Q_{s k y}$ は, 単独時の $\delta Q_{s k y}$ より大きな值となっている 可能性が考えられる。Fig.10に併用時の接合面の応力状態の概念を 示す。円柱状シアキーに生じる軸力 $N_{s k y}$ は， $\delta_{V}$ によるアンカー筋に 生じる軸力 $T$ との応力の釣り合いより, 増大していると推定される。 次節では, 実験結果によるアンカー筋のひずみから, 接合面に生じ る軸応力を評価していく。

\section{3 接合面に生じる軸応力の推定}

Fig.10 に示すように， $T$ (アンカー筋の引張軸力を正とする）の 鉛直成分 ${ }_{v} N_{a}$ (接合面に対する圧縮軸力方向を負とする),$N$ 及び $N_{s k y}$ による応力の釣り合いから， $N_{s k y}$ は次式により算定される。

$$
N_{\text {sky }}=N-{ }_{v} N_{a}
$$

アンカー筋の引張軸力によって付加される接合面の圧縮応力度は, $T$ の鉛直方向成分であることから， $\delta_{H}$ と $\delta_{V}$ の関係により, 次式で算 定することができる。

$$
{ }_{v} N_{a}=-T \cdot n_{a} \cdot \sin \left(\tan ^{-1}\left(\frac{\delta_{V}}{\delta_{H}}\right)\right)
$$

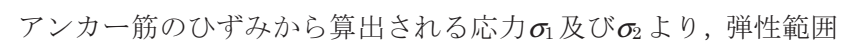
内の $T$ と曲げモーメント $M$ は, それぞれ式(31)と式(32)で算定され, $T, M$ からアンカー筋の降伏時の応力 $\sigma_{y}$ は式(33)で算定される。

$$
T=\frac{\left(\sigma_{1}+\sigma_{2}\right)}{2} \cdot \frac{\pi d_{a}^{2}}{4}
$$

$$
\begin{aligned}
& M=\frac{\left(\sigma_{1}-\sigma_{2}\right)}{2} \cdot \frac{\pi d_{a}{ }^{3}}{32} \\
& \sigma_{y}=\frac{M}{Z_{a}}+\frac{T}{A_{e}}
\end{aligned}
$$

ここに， $Z_{a}$ はアンカー筋の断面係数， $A_{e}$ はアンカー筋の断面積で ある。

式(31), (32)からアンカー筋が弾性範囲内である $\delta_{H}=0.25 \mathrm{~mm}$ 時の アンカー筋の $M$ 分布と $T$ 分布の一例を Fig. 11 に示す。 $\mathrm{AS}$ シリーズ の $M$ は, A シリーズより小さい值を示し, AS シリーズの $T$ は A シ リーズより大きい值を示している。このことからも, 著者らが推察 したように， $C_{\delta} Q_{a}$ は $\delta Q_{a}$ より小さいと判断される。

接合面に生じる軸応力を推定する手法を引き続き検討する。既往 の研究からアンカー筋に塑性ヒンジが生じる, 埋め込み深さ $I_{e}$ は, $C \sigma_{B}$ が大きい程，接合面に近くなると報告されている ${ }^{16)}$ 。この傾向 は, Fig.11(a) と (b)を比較すると, $c \sigma_{B}$ が大きい程, $M$ の最大值が接 合面に近づいていることからも理解できる。このことから， $c \sigma_{B} に も$ よるが最初に $\sigma_{y}$ に達する既存部コンクリート側の $I_{e}$ は, 同図より $l_{e}$ $=0.5 d_{a}$ から $l_{e}=2 d_{a}$ の範囲にあると観察されるため, 本論文では比較 的ばらつきが小さい $l_{e}=2 d_{a}$ の $M$ と $T$ の值を用いて, アンカー筋が 降伏したから゙うかを判断する。また， ${ }_{v} N_{a}$ を推定するには，極力接合

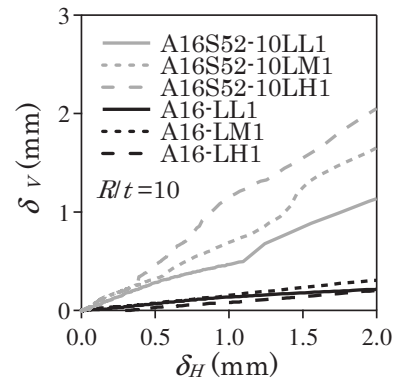

(a) Bearing failure

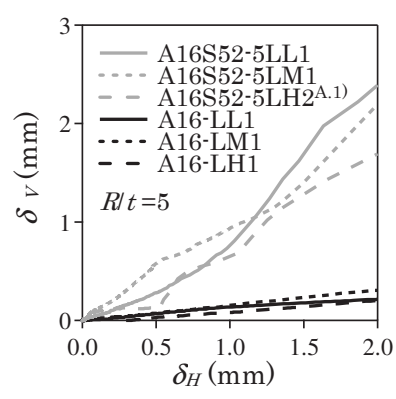

(b) Shear-off failure
Fig. $8 \quad \delta_{V}-\delta_{H}$ relations

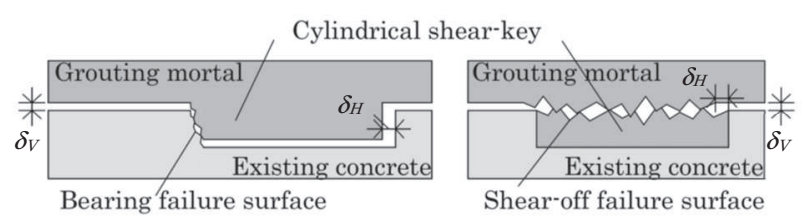

(a) Bearing failure

(b) Shear-off failure

Fig. 9 Behavior for each assumed failure mode

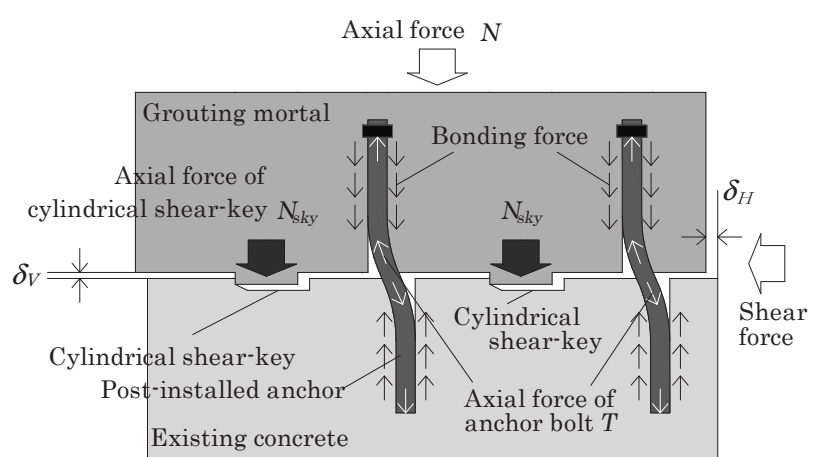

Fig. 10 Concept of stress field of joint surface of combination 


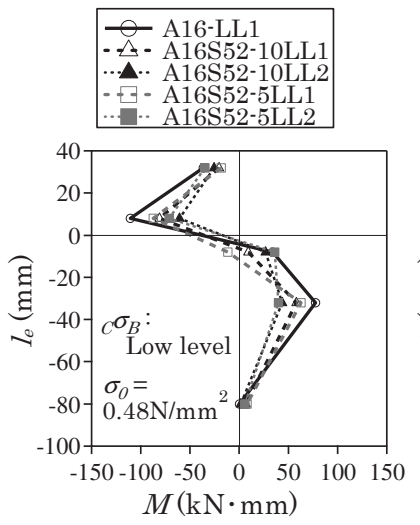

(a) $M$ distribution $\left(c \sigma_{B}:\right.$ Low level)
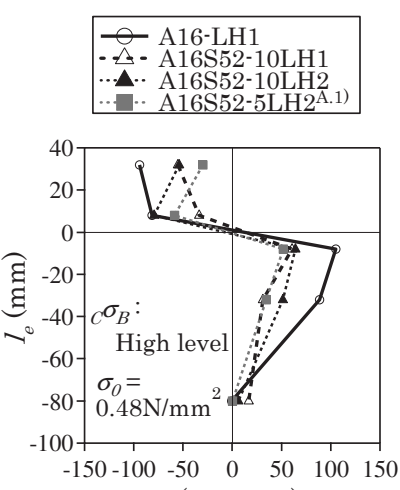

$M(\mathrm{kN} \cdot \mathrm{mm})$

(b) $M$ distribution

(c和 : High level)

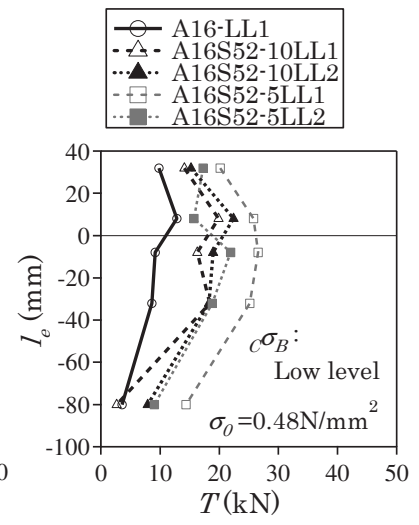

(c) $T$ distribution (c $\sigma_{B}$ : Low level)

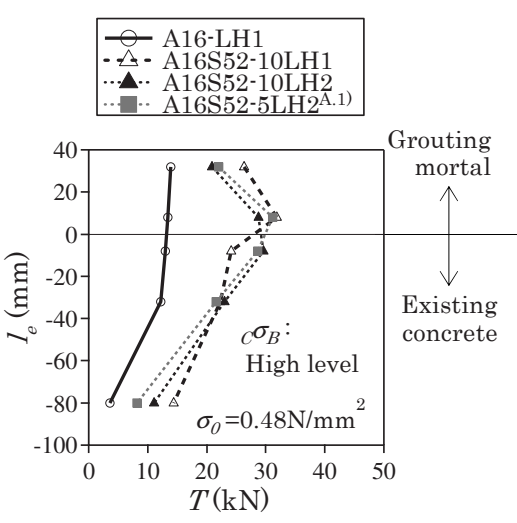

(d) $T$ distribution $\left(c \sigma_{B}:\right.$ High level)

Fig. 11 Example of $M$ distribution and $T$ distribution of anchor bolt at $\delta_{H}=0.25 \mathrm{~mm}$

面に近い軸力 $T$ の值を用いることが適切であることから， ${ }_{V} N_{a}$ は既 存部コンクリート側 $l_{e}=0.5 d_{a}$ と補強部グラウト側 $l_{e}=0.5 d_{a}$ の $T$ の平 均值を用いて算定寸る。以上より，本論文では下記の手順で接合面 に生じる軸応力を推定する。

1)既存部コンクリート側 $l_{e}=2 d_{a}$ において, 式(33)により算定した

$\sigma_{y}$ に達した時のせん断変位 $\delta_{H y}$ を実験結果から求める。

2) $\delta_{H_{y}}$ 時の $T$ を既存部コンクリート側 $l_{e}=0.5 d_{a}$ と補強部グラウト

側 $l_{e}=0.5 d_{a}$ のひずみから，式(31)によりそれぞれ算定する。

3) ${ }_{V} N_{a}$ を上記 2)で算定された AS シリーズの $T$ の平均值を用い,

式(30)により算定する。

アンカー筋の引張による降伏荷重 $T_{a}\left(=\sigma_{y} \times A_{e}\right)$ に対する, 上記の手 順で導いた $T$ の比 $T / T_{a}$ と $\delta_{H y}$ 関係を観察する。Fig.12に $T / T_{a}-\delta_{H}$ 関係を示す。同図より, $T / T_{a}$ の平均值は $\mathrm{A}$ シリーズで $0.18, \mathrm{AS}$ シ リーズで 0.41 であり, AS シリーズの方が大きい值を示している。 また， AS シリーズの円柱状シアキーの破壊形式毎の $T / T_{a}$ の平均值 は，支圧破壊型で 0.40 , シアオフ破壊型で 0.43 であるため，顕著な 違いは見られない。

${ }_{{ }} N_{a}$ を $A$ で除した值を, ${ }_{V} N_{a}$ による接合面の平均圧縮応力度 ${ }_{a} \sigma_{0}$ と すると，a的は次式で算定される。

$$
{ }_{a} \sigma_{0}={ }_{v} N_{a} / A
$$

${ }_{a} \sigma_{0}-\delta_{H_{y}}$ 関係を Fig.13 に示す。 $l_{e}=0.5 d_{a}$ のアンカー筋のひずみは, 接合面に近く, ひずみが大きく変動する箇所であることや計測位置 の若干のずれ等によりばらつきは見られるが, AS シリーズの ${ }_{a} \sigma_{0}$ の 平均值は-0.60N $/ \mathrm{mm}^{2}$ であり, $\mathrm{A}$ シリーズの ${ }_{a} \sigma_{0}$ は- $0.05 \mathrm{~N} / \mathrm{mm}^{2}$ であ った。これより $\mathrm{A}$ シリーズの ${ }_{a} \sigma_{0}$ は非常に小さい值であるが，併用 時の ${ }_{a} \sigma_{0}$ はせん断力に影響するほど大きな值を呈している。また, $\delta_{H_{y}}$ においても ${ }_{a} \sigma_{0}$ と同様の理由でばらつきが生じていると思われる が, 実験パラメータによる明確な違いが見られないことから, 以降 の検討はこのばらつきを含めて評価する。

\section{5. 併用時のカ学モデルの構築}

本章では, 前章で求めた $T$ 及び ${ }_{a} \sigma_{0}$ を用い, 修正モデルを提案す る。その後，修正モデルと実験值を比較する。

\section{1 力学モデル}

修正モデルのせん断変位 $\delta_{H}$ 時の接合面のせん断力 $C_{\delta} Q$ は, $C_{\delta} Q_{a}$ と

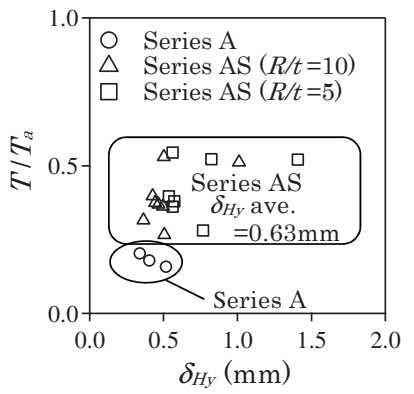

Fig. $12 T / T_{a}-\delta_{H_{y}}$ relations

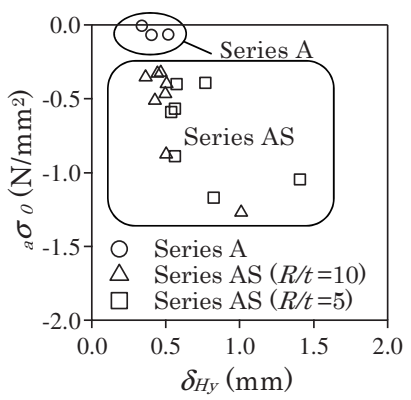

Fig. $13{ }_{a} \sigma_{0}-\delta_{H_{y}}$ relations

$c_{\delta} Q_{s k y}$ の変形を考慮した累加が成立すると考えると, 次式のように 表せる。

$$
{ }_{\delta}^{C} Q={ }_{\delta}^{C} Q_{a}+{ }_{\delta}^{C} Q_{s k y}
$$

はじめに，修正モデルにおけるあと施エアンカーの力学モデルを 検討するため，併用時におけるあと施工アンカーが負担するせん断 力の低下率 $C_{\delta} Q_{a} / \delta Q_{a}$ の值を推定する。一般に引張応力とせん断応力 の組み合わせ応力を受ける構造部材の設計で用いられる次式が，あ と施工アンカーの耐力評価にも用いられる 9),14)。

$$
\left(\frac{T}{T_{a}}\right)^{C_{\alpha}}+\left(\frac{Q_{y}}{Q_{a}}\right)^{C_{\alpha}}=1
$$

ここに， $Q_{a}$ はあと施工アンカーのせん断耐力， $Q_{y}$ はせん断変位 $\delta_{H_{y}}$ 時のあと施工アンカーが負担するせん断力， ${ }^{C} \alpha$ は係数である。

Fig. 12 より $\mathrm{AS}$ シリーズの $\delta_{H_{y}}$ の平均值は $0.63 \mathrm{~mm}$ であり, この 時の ${ }^{C} \alpha$ は $0.75 \sim 1.00$ 程度 14$)$ であると報告されている。これから， $Q_{y} / Q_{a}$ を式(36)より算定すると $\mathrm{AS}$ シリーズの $Q_{y} / Q_{a}$ は $\mathrm{A}$ シリーズ の約 0.7 倍となるため,ここでは $C_{\delta} Q_{a}=0.7_{\delta} Q_{a}$ として検討を試みる。

続いて修正モデルにおける円柱状シアキーの力学モデルについて 述べる。 $\delta_{H_{y}}$ 時の $N_{s k y}$ は式(29)から算定され，併用時の接合面の平均 圧縮応力度 ${ }^{C} \sigma_{0}$ 及び円柱状シアキーに作用する平均圧縮応力度 ${ }^{C} \sigma o$ は，それぞれ式(37)と式(38)から求められる。

$$
\begin{aligned}
& { }^{C} \sigma_{0}=\sigma_{0}-{ }_{a} \sigma_{0} \\
& { }^{C} \sigma_{0}^{\prime}=\frac{N_{s k y}}{{ }_{p} A_{s k y}}=\frac{\left(N-{ }_{a} \sigma_{0} \cdot A\right)}{{ }_{p} A_{s k y}}
\end{aligned}
$$

4.3 節で求めた ${ }_{a} \sigma_{0}=-0.60 \mathrm{~N} / \mathrm{mm}^{2}$ を用い, 式(12) (14), (20), (25) 
及び(27)に $\sigma_{0}$ を ${ }^{C} \sigma_{0}$ に， $\sigma_{0}{ }^{\prime}$ を ${ }^{C} \sigma_{0}$ にそれぞれ代入する。また, 4.2 節 で述べた通り, 併用時の力学挙動は比較的緩やかに $\delta_{H}=1 \mathrm{~mm}$ 近傍ま で $Q$ が増大していることから, 併用時の $\delta_{\max 1}$ は単独時より大きく なっていると推察される。このことに関連して, 既往の研究でも同 様の傾向が報告されている。奥山らの研究 17)では, チッピングによ る目荒らしが, 微小凹凸面に作用寸る接触応力を用いてモデル化さ れている。ここで目荒らし単独の場合には, 接触応力のピーク時の 変位 (本論文の $\delta_{\operatorname{maxl}}$ に該当する) が $0.08 \mathrm{~mm}$ とされているが，あと 施工アンカーと併用した場合には, $0.8 \mathrm{~mm}$ に修正されている。この 修正により, 過大に評価していた岡性が改善され, 実験值の再現精 度が向上したと報告されている ${ }^{17)}$ ここで Fig.7 を改めて観察する と, 4.2 節で述べた通り, 修正前モデルは実験值と比較して剛性が 高く評価されている。このことより, 円柱状シアキーとあと施工ア ンカーを併用した場合の $\delta_{\max 1}$ も, 単独時の $0.2 \mathrm{~mm}$ より大きな值と なることが推測される。そこで, アンカー筋の降伏領域に達するま で, 円柱状シアキーの力学挙動が荷重漸増領域にあると考えると, 併用時の $\delta_{\max 1}$ は $\mathrm{AS}$ シリーズの $\delta_{H_{y}}$ の平均值 $0.63 \mathrm{~mm}$ となり, 奥山 らの研究と同様の傾向となる。

以上を整理すると併用時の円柱状シアキーの力学モデルは Fig.14のように表せる。Fig.14 に併用時の円柱状シアキーの力学モ デルを示す。ここで, 同図に示す各領域の開始点が逆転しないこと, つまり $\delta_{\max 1}$ が $\delta_{\max 2}$ より大きな值とならないように, 併用時の円柱 状シアキーの $\delta_{\max 1}=0.63 \mathrm{~mm}$ (ただし,$\delta_{\max 1} \leqq \delta_{\max 2}$ ） は次式に示すよ う定める。

$$
\delta_{\max 1}=\min \left(0.63, \delta_{\max 2}\right)
$$

\section{2 計算值と実験值の比較}

前節より併用時の接合面の軸応力の状態を整理すると, 修正モデ

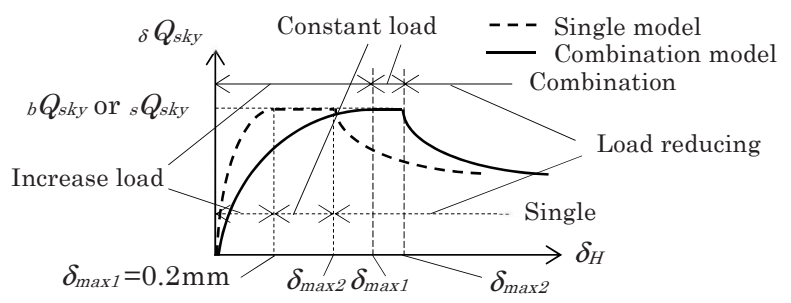

Fig. 14 Mechanical model using combination of cylindrical shear-key

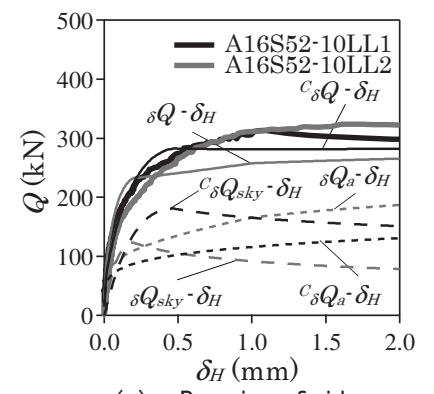

(a) Bearing failure

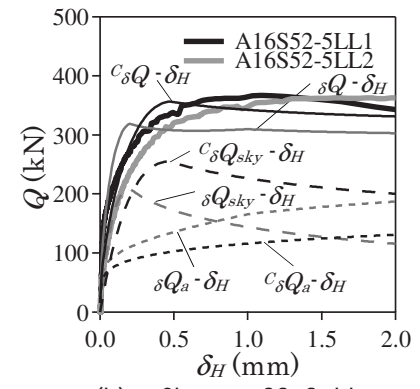

(b) Shear-off failure (A16S52-5LL1, 2)
(A16S52-10LL1, 2)

Fig. 15 Example of comparison between $c_{\delta} Q-\delta_{H}$ relations and $\delta Q-\delta_{H}$ relations
ルは下記の条件により算定される。

1)修正モデルのあと施工アンカーの力学モデルは, $C_{\delta} Q_{a}=0.7_{\delta} Q_{a}$ として求める。

2)修正モデルの円柱状シアキーの力学モデルは, 修正前モデルの

円柱状シアキーの力学モデルにおける $\sigma_{0}$ を ${ }^{C} \sigma_{0}$ に, $\sigma_{0}$ をを ${ }^{C} \sigma_{o}$ に 各々置換して求める。また， $\delta_{\max 1}$ は式(39)により算定される。 実験值と修正モデルによる計算值を比較する。まず, Fig.15 に修 正モデルの $C_{\delta} Q-\delta_{H}$ 関係と, 修正前モデルの $\delta Q-\delta_{H}$ 関係の比較の一例 を示す。 $C_{\delta} Q-\delta_{H}$ と $\delta Q-\delta_{H}$ 関係を比較すると, $\delta_{H}=0.5 \mathrm{~mm}$ 近傍までの 剛性と耐力は, 修正モデルである $C_{\delta} Q-\delta_{H}$ 関係の方が, 修正前モデル $の_{\delta} Q-\delta_{H}$ 関係より実験值に近い值を推移している。また， $C_{\delta} Q_{s k y}$ は ${ }_{a} \sigma_{0}$ の影響で $\delta Q_{s k y}$ より大きい值を， $C_{\delta} Q_{a}$ は $T$ の影響で $\delta Q_{a}$ より小さ い值となる。他の試験体においても $C_{\delta} Q-\delta_{H}$ 関係の観察を続ける。
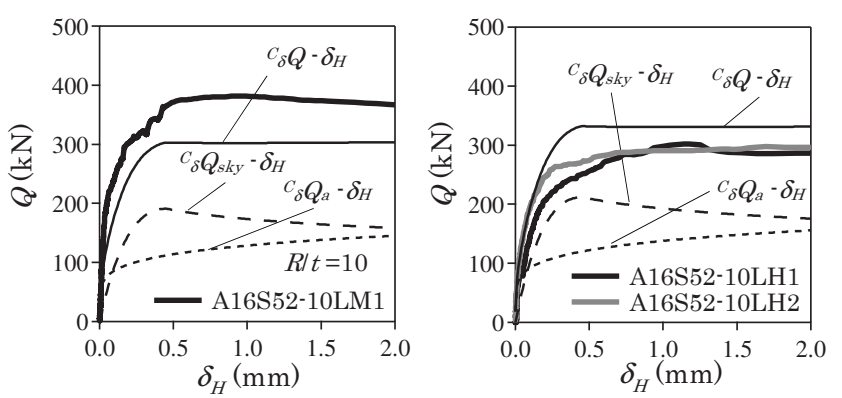

(a) A16S52-10LM1

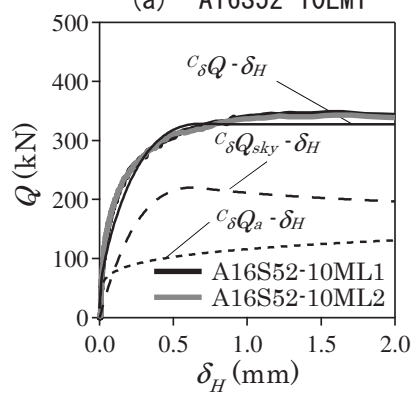

(b) A16S52-10LH1, 2

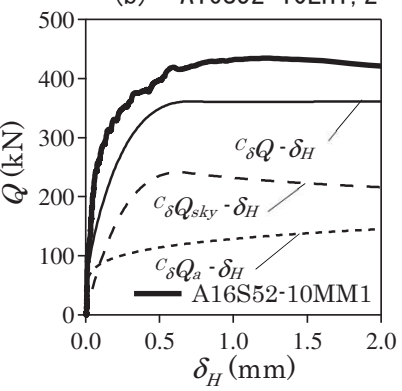

(c) A16S52-10ML1, 2

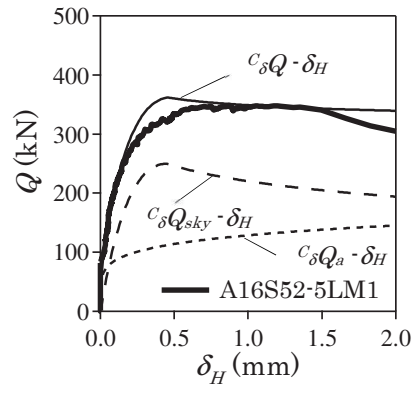

(d) A16S52-10MM1

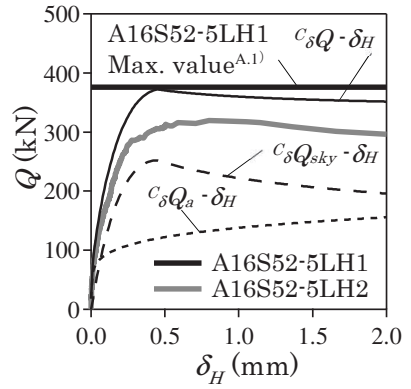

(e) A16S52-5LM1

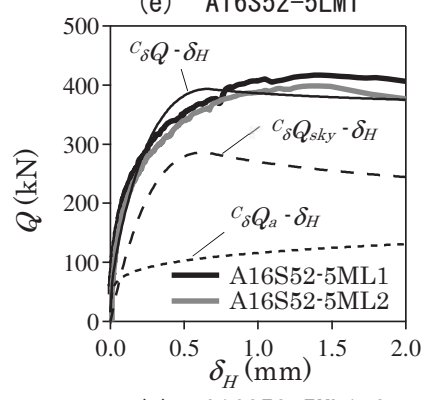

(f) A16S52-5LH1, 2

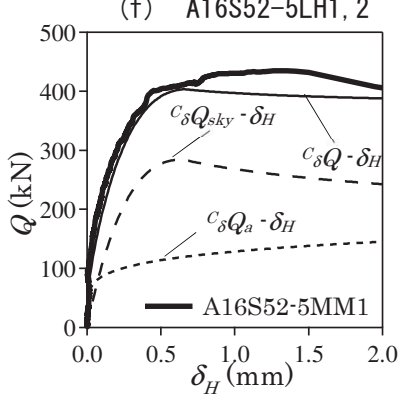

(h) A16S52-5MM1

Fig. $16 \quad Q-\delta_{H}$ relations of modified model 


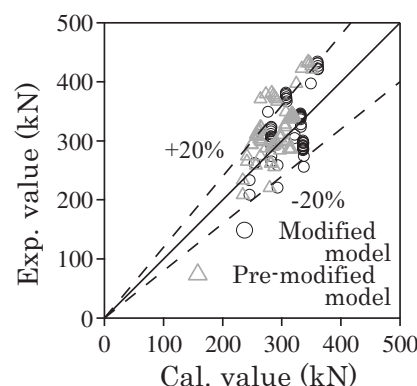

Cal. value $(\mathrm{kN})$

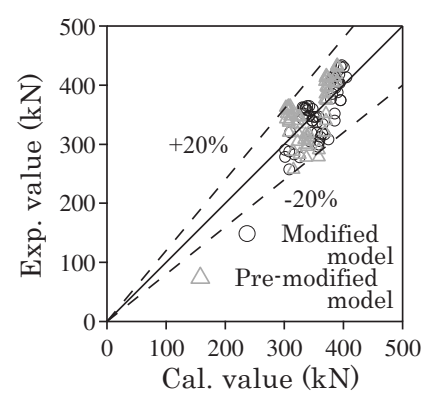

(b) Shear-off failure
Fig. 17 Comparison between Exp. value and Cal. value at $\delta_{H}=0.25,0.50,0.75 .1 .00,1.25,1.50,1,75,2.00 \mathrm{~mm}$

Table 2 Average and standard deviation for each failure mode (Value obtained by dividing exp. value by cal. value)

\begin{tabular}{|c|c|c|c|c|}
\hline Failure mode & \multicolumn{2}{|c|}{ Bearing failure } & \multicolumn{2}{|c|}{ Shear-off failure } \\
\hline Model & $\begin{array}{c}\text { Pre- } \\
\text { modified } \\
\text { model }\end{array}$ & $\begin{array}{c}\text { Modified } \\
\text { model }\end{array}$ & $\begin{array}{c}\text { Pre- } \\
\text { modified } \\
\text { model }\end{array}$ & $\begin{array}{c}\text { Modified } \\
\text { model }\end{array}$ \\
\hline Average & 1.11 & 1.04 & 1.03 & 0.99 \\
\hline $\begin{array}{c}\text { Standard } \\
\text { deviation }\end{array}$ & 0.13 & 0.13 & 0.11 & 0.09 \\
\hline
\end{tabular}

Fig.16に修正モデルの $Q-\delta_{H}$ 関係を示す。試験体によりばらつきが 生じているが, 修正モデルは概ね実験による力学挙動を捉えている。 次に実験值と修正モデルによる計算值の相関性を数值的に検証す る。まず，試験体毎に $\delta_{H}=0.25 ， 0.50 ， 0.75 .1 .00 ， 1.25 ， 1.50 ， 1,75$, $2.00 \mathrm{~mm}$ における各点の実験值と計算值の比較を Fig. 17 に示し,

Fig.17に対応した円柱状シアキーの破壊形式毎に実験值を計算値 で除した值の平均值と標準偏差を Table 2 に示す。修正モデルにお いて, 平均值と標準偏差から計算值が実験值の $\pm 20 \%$ 以内に納まる 確率は, 支圧破壊とシアオフ破壊でそれぞれ 0.74 から 0.85 に, 0.92 から 0.98 に上昇している。このことから, 修正モデルの剛性や耐力 は, 修正前モデルより実験值に近づいたと判断される。

また，上記の方法では純粋な計算值の実験值に対する誤差の度合 いを評価できないため, 残差平方和 $R S S m$ を用いて, 修正モデルと 修正前モデルのフィッティングの度合いを評価する。次式により,

$R S S m$ を算定する。

$$
R S S m=\sum_{i=1}^{8}\left\{1-{ }_{\delta} Q_{\text {exp } .}\left(\delta_{H i}\right) /{ }_{\delta} Q_{\text {cal } .}\left(\delta_{H i}\right)\right\}^{2}
$$

ここに, $i$ は 1 から 8 の整数のステップ番号で, せん断変位 $\delta_{H i}=0.25$ $\times i \mathrm{~mm}$ である。また， ${ }_{\delta} Q_{\text {exp. }}\left(\delta_{H i}\right)$ はせん断変位 $\delta_{H i}$ 時の実験值, ${ }_{\delta} Q_{c a l .}\left(\delta_{H i}\right)$ はせん断変位 $\delta_{H i}$ 時の計算值である。

修正モデルにおける破壊形式毎の試験体の RSSmの総和は, 修正 前モデルと比べ，支圧破壊では 1.88 から 1.26 に，シアオフ破壊で は 0.75 から 0.41 に改善している。

以上の 2 つの検証結果からも, 接合面の軸応力状態や力学挙動を 考慮した修正モデルの方が, 修正前モデルより実験值を推定する精 度が向上していると判断される。

\section{6. 結論}

本論文では, 円柱状シアキーとあと施工アンカーを併用した試験 体のせん断実験を行い, その実験結果から接合面の軸応力による応
力状態を推定し, 更に力学挙動を詳細に検討した。その結果, これ らの影響を反映した併用時の力学モデルである修正モデルは, 単に 累加した力学モデルである修正前モデルより，実験值を推定する精 度が向上した。以下に本論文で得られた知見を示す。

1)せん断変位 $\delta_{H}$ が概ね $0.2 \mathrm{~mm}$ 以下の範囲において, 修正前モデ ルは実験值より剛性が高く，せん断力が大きく評価され，それ 以降の $\delta_{H}$ においては，修正前モデルが実験值より小さい值を推 移している。

2)支圧破壊型の円柱状シアキーは， $\delta_{H}$ の増大により円柱状シアキ 一の側面が損傷し，その損傷面を乗り越えるような挙動を呈す ることから，目開き変位 $\delta_{V}$ が増大寸ると思われる。また，シアオ フ破壊型の円柱状シアキーについては, シアオフ破壊後, 破壊面 の凹凸による噛み合い抵抗が生じることから $\delta_{H}$ の増大に伴い $\delta_{V}$ も増大すると考えられる。その結果, あと施工アンカー単独時の $\delta_{V}$ は， $\delta_{H}$ の $1 / 10$ 程度であるが，併用時の $\delta_{V}$ は概ね $\delta_{H}$ の $1 / 2$ から 同程度の範囲を推移した。

3)単独時より併用時のアンカー筋の引張軸力 $T$ が大きくなり, 曲 げモーメント $M$ は小さくなる。この $T$ 小值から併用時のあと施 エアンカーが負担するせん断力 $C_{\delta} Q_{a}$ は, 単独時のあと施工アン カーが負担するせん断力 $\delta Q_{a}$ の約 0.7 倍であると推定できる。

4) $T$ の鈆直成分により接合面に付加される軸力 ${ }_{V} N_{a}$ を接合面の面 積 $A$ で除した，接合面の平均圧縮応力度 ${ }_{a} \sigma_{0}$ の平均值は $-0.60 \mathrm{~N} / \mathrm{mm}^{2}$ であり, 併用時の接合面の平均圧縮応力度 ${ }^{C} \sigma_{0}$ 及び 円柱状シアキーに生じる平均圧縮応力度 $C_{\boldsymbol{\sigma}} \boldsymbol{\sigma}_{0}$ は, 修正前モデルの それぞれの圧縮応力度に ${ }_{a} \sigma_{0}$ を加味して評価する。その結果, 併 用時の円柱状シアキーが負担するせん断力 $C_{\delta} Q_{s k y}$ は, 単独時の 円柱状シアキーが負担するせん断力 $\delta Q_{s k y}$ より大きくなる。

5)アンカー筋の降伏領域に達するまで円柱状シアキーの力学挙動 が荷重漸増領域にあると考えると, 円柱状シアキーの力学モデ ルによるせん断耐力に達した時の $\delta_{H}$ である $\delta_{\max 1}$ は，アンカー筋 の降伏応力 $\sigma_{y}$ に達した時のせん断変位 $\delta_{H y}$ の平均值 $0.63 \mathrm{~mm}$ を 用いることができる。

6)修正モデルは，上記 3)～5)を考慮して構築されている。その結 果, 計算值が実験值の $\pm 20 \%$ 以内に納まる確率は, 修正前モデル と修正モデルを比較すると，支圧破壊とシアオフ破壊でそれぞ れ 0.74 から 0.85 に, 0.92 から 0.98 に上昇した。また, 残差平 方和を用いて評価した場合においても，修正モデルは修正前モ デルより実験值を推定する精度が向上した。

なお，本論文が対象とする部位は，グラウトを用いる間接接合部 の接合面であり, 提案する力学モデルは圧縮応力下でせん断応力が 作用する場合である。実構造物において, どのような軸力が作用し ているか評価することは極めて難しく, 現状では安全側の軸応力を 設定して設計する必要がある。しかし，今後はこの問題を解決し合 理的で柔軟な接合部の設計を実現できるよう, 検討する予定である。

\section{参考文献}

1) Japan Building Disaster Prevention Association: Guidelines for Seismic Retrofit Design of Existing Reinforced Concrete Buildings, 2017 (in Japanese)

日本建築防災協会: 2017 年改訂版 既存鉄筋コンクリート造建築物の而 震補強改修設計指針・同解説，日本建築防災協会，2017 
2) Musha, U., Takase, Y., Abe, T., Sakamoto, K., Hiwatashi, T. and Katori, K.: Supported Strength Formula of Roughened Concrete Using Shape Measurement Value by 3D-Scanner, AIJ Journal of Technology and Design, Vol. 25, No. 59, pp. 55-60, 2019. 2 (in Japanese)

武者右京, 高瀬裕也, 阿部隆英, 坂本啓太, 樋渡健, 香取慶一: 既存コ ンクリート目荒らし面における $3 \mathrm{D}$ スキャナを用いた形状座標值による せん断耐力式, 日本建築学会技術報告集, 第 25 巻, 第 59 号, pp. 5560, 2019. 2

3) Abe, T., Hiwatashi, T., Takase, Y. and Katori, K.: Mechanical Model of Cylindrical Shear-key Applied to Seismic Retrofitted Joint of Concrete Structure, Concrete Journal, Vol. 30, pp. 11-20, 2019. 7 (in Japanese) 阿部隆英, 樋渡健, 高瀬裕也, 香取慶一: コンクリート構造物の而震補 強の接合部に適用する円柱状シアキーの力学モデルの構築, コンクリ 一ト工学論文, 第 30 巻, pp. 11-20, 2019. 7

4) Abe, T., Hiwatashi, T., Takase, Y. and Katori, K.: Mechanical Model of Post-installed Anchor Considered of Behavior of Concrete and Grout Using Reaction Modulus, JCI Annual Convention Proceedings, Vol. 40, No. 2, pp. 970-984, 2018. 6 (in Japanese)

阿部隆英, 樋渡健, 高瀬裕也, 香取慶一: 反力係数を用いて補強部と既 存部の挙動を評価した接着系あと施工アンカーの力学モデル, コンクリ 一ト工学年次論文集, 第 40 巻, 第 2 号, pp. 979-984, 2018. 6

5) Nakano, K. and Matsuzaki, Y.: Additional Method of Shear Resistances in Precast Concrete Connections, Journal of Structural and Construction Engineering (Transactions of AIJ), No. 550, pp. 151158, 2001. 12 (in Japanese)

中野克彦, 松崎育弘: プレキャスト RC 部材接合面におけるせん断抵抗 要素の耐力累加方法, 日本建築学会構造系論文集, 第 550 号, pp. 151158, 2001. 12

6) Mochizuki, S., Makitani, E. and Nagasaka, T.: Ultimate Shear Strength of Vertical Connections Between Precast Concrete Wall Panels, Journal of Structural and Construction Engineering (Transactions of AIJ), No. 424, pp. 11-22, 1991. 6 (in Japanese) 望月重, 槇谷栄次, 永坂具也: 壁式プレキャスト構造鉛直接合部のせん 断耐力 - ダウエル効果および圧縮拘束力を考慮した場合 - , 日本建築 学会構造系論文報告集，第 424 号, pp. 11-22, 1991. 6

7) Kokusyo, S.: Study on the Strength of Joints in Reinforced Concrete Precast Structures, Transactions of the Architectural Institute of Japan, No. 89, p. 141, 1963. 9 (in Japanese)

黒正清治: プレカストコンクリート構造接合部耐力に関する研究（打継 ぎ部の形状と強度について), 日本建築学会論文報告集, 第 89 号（昭和 38 年度大会学術講演要旨集), p. 141, 1963.9

8) Samata, K., Matsuzaki, Y., Kimura, H., Takahashi, K. and Watanabe, M.: Experimental Study on Vertical Joints of Precast Panels Used a Wall Form (Part 5. Classification of Failure Mode), Summaries of Technical Papers of Annual Meeting, Architectural Institute of Japan, Structures II, pp. 741-742, 1991. 7 (in Japanese)

佐俣紀一郎, 松崎育弘, 木村博, 高橋啓, 渡辺正人：壁式プレキャスト 鉄筋コンクリート構造の鉛直接合部に関する実験研究, その 5 破壊モ ードの分類, 日本建築学会大会学術講演梗概集, 構造 II, pp. 741-742, 1991. 7

9) Japan Building Disaster Prevention Association: External Seismic Retrofitting Manual, 2002 (in Japanese)

日本建築防災協会：既存鉄筋コンクリート造建築物の「外側而震改修マ ニュアル」, 2002

10) Takase, Y., Abe, T., Itadani, H., Satou, T., Kubota, M. and Ikeda, T.: Estimation Method of Horizontal Capacity of Joint Fracture for Retrofitted Frame Using Disk Shear-key, Study on Shear-key Consisted of Steel Disk and Anchor Bolt for Seismic Retrofitting, Journal of Structural and Construction Engineering (Transactions of AIJ), Vol. 79, No. 698, pp. 507-515, 2014. 4 (in Japanese)

高瀬裕也, 阿部隆英, 板谷秀彦, 佐藤貴志, 久保田雅春, 池田隆明: デ イスク型シヤキーを用いた内付け補強架構の接合部破壊時の保有水平 耐力の評価手法 - 鋼製ディスクとアンカーボルトを併用した耐震補強 用シヤキーに関する研究 -, 日本建築学会構造系論文集, 第 79 巻, 第 698 号, pp. 507-515, 2014. 4
11) Abe, T., Hiwatashi, T., Kubota, M., Takase, Y. and Katori, K.: Development and Equation for Shear Strength of Cylindrical Shearkey Applied Seismic Retrofitted Joint of Concrete Structure, Journal of Structural and Construction Engineering (Transactions of AIJ), Vol 82, No. 736, pp. 873-883, 2017. 6 (in Japanese)

阿部隆英, 樋渡健, 久保田雅春, 高瀬裕也, 香取慶一：コンクリート構 造物の耐震補強の接合部に適用する円柱状シアキーの提案と耐力式の 構築 一 円柱状シアキーを用いた間接接合部に関する研究 - , 日本建築 学会構造系論文集, 第 82 巻, 第 736 号, pp. 873-883, 2017.6

12) Takahashi, M., Watanabe, K., Tanuma, T., Nakano, K., Hamasaki, H. and Owa, S.: Short-term Bond Strength Experiment of Slow Curing Adhesive Anchor in Combination of Borehole Types and Concrete Temperature, Summaries of Technical Papers of Annual Meeting, Architectural Institute of Japan, Structures IV, pp. 65-66, 2013. 7 (in Japanese)

高橋宗臣，渡辺一弘，田沼毅彦，中野克彦，濱崎仁，大和征良：穿孔機 械と母材温度の違いによる注入方式あと施工アンカーの短期付着性能 実験, 日本建築学会大会学術講演梗概集, 構造IV, pp. 65-66, 2013. 7

13) Nakachi, T.: Experimental Study on Quantity of Cotters on Precast Reinforced Concrete Core Walls, Summaries of Technical Papers of Annual Meeting, Architectural Institute of Japan, Structures IV, pp. 173-174, 2016. 7 (in Japanese)

仲地唯治: RC 造プレキャストコア壁におけるコッター数に関する実験 的研究, 日本建築学会大会学術講演梗概集, 構造IV, pp. 173-174, 2016. 7

14) Takase, Y., Wada, T., Ikeda, T., Shinohara, Y. and Mizoguchi, M. Mechanical Behavior and Work of Adhesive Post-installed Anchors Subjected to Cyclic Shear Force and Constant Tensile Force, Journal of Structural and Construction Engineering (Transactions of AIJ), Vol. 82, No. 738, pp. 1255-1263, 2017.8 (in Japanese)

高瀬裕也, 和田俊良, 池田隆明, 篠原保二, 溝口光男：一定引張力を受 けながら繰り返しせん断応力を受ける接着系あと施工アンカーの力学 挙動と仕事量, 日本建築学会構造系論文集, 第 82 巻, 第 738 号, pp. 1255-1263, 2017. 8

15) Takase, Y: Testing and modeling of dowel action for a post-installed anchor subjected to combined shear force and tensile force, Engineering Structures, Vol. 195, pp. 551-558, 2019. 6

16) Takase, Y., Wada, T., Ikeda, T. and Shinohara, Y.: Mechanical Model of Adhesive Post-installed Anchor Subjected to Cyclic Shear Force, Journal of Structural and Construction Engineering (Transactions of AIJ), Vol. 77, No. 682, pp. 1915-1924, 2012. 12 (in Japanese) 高瀬裕也, 和田俊良, 池田隆明, 篠原保二: 繰り返しせん断力を受ける 接着系あと施エアンカーの力学モデル, 日本建築学会構造系論文集, 第 77 巻, 第 682 号, pp. 1915-1924, 2012. 12

17) Okuyama, Y., Takase, Y., Abe, T. and Hiwatashi, T.: Fundamental Study on Combination of Dowel Action and Shear Transfer on Concrete Roughening for Seismic Retrofit Joint, Concrete Journal, Vol. 30, pp. 35-43, 2019. 7 (in Japanese)

奥山裕希恵, 高瀬裕也, 阿部隆英, 樋渡健：耐震補強接合部におけるあ と施エアンカーのダウエル効果と目荒らし面の噛み合い効果の累加に 関する検証, コンクリート工学論文, 第 30 巻, pp. 35-43, 2019. 7

付録＼cjkstart試験体 A16S52-5LH1 の実験値について

A.1）試験体 A16S52-5LH1 では, 接合面のせん断変位 $\delta_{H}$ を計測できなかった ため, Fig.8 及び Fig.11 では, 試験体 A16S52-5LH2 を表示した。また, Fig.16(f)では, 試験体 A16S52-5LH1 の最大せん断力の夕を図示した。

\section{注}

注 1)エポキシ樹脂系接着剤の機械的性質は以下の通りである。

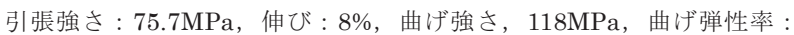
$3540 \mathrm{MPa}$, 圧縮強さ: $109 \mathrm{MPa}$, 圧縮弾性率 : $2730 \mathrm{MPa}$

注 2)本論文では，平均付着強度 $21.9 \mathrm{~N} / \mathrm{mm}^{2}$ のエポキシ樹脂系接着剂 12)を用 いた。この試験条件は下記に示す通りである。

【付着強度試験条件】

穿孔方法 : 湿式コアドリル, 有効埋め込み深さ : $5 d_{a}(60 \mathrm{~mm})$, アンカー 筋径 : M12, アンカー筋材質 : SNB7, 気中温度 : 約 $23^{\circ} \mathrm{C}$ 
PROPOSAL OF MECHANICAL MODEL CONSIDERING STRESS FIELD OF JOINT SURFACE

IN THE CASE OF COMBINED USE OF POST-INSTALLED ANCHOR AND CYLINDRICAL SHEAR-KEY

Study on indirect joints with cylindrical shear-key

\author{
Takahide ABE ${ }^{* 1}$, Keita SAKAMOTO ${ }^{* 2}$, Takeshi HIWATASHI ${ }^{* 3}$, \\ Yuya TAKASE*4 and Keiichi KATORI*5 \\ ${ }^{* 1}$ Chief, Seismic Solution Dept., TOBISHIMA Corporation \\ ${ }^{* 2}$ Chief, Seismic Solution Dept., TOBISHIMA Corporation, M.Eng. \\ ${ }^{*}$ Senior Researcher, Research and Development Center, TOA Corporation, Dr.Eng. \\ ${ }^{*}$ Assoc. Prof., College of Design and Manufacturing Technology, Muroran Institute of Technology, Dr.Eng. \\ ${ }^{* 5}$ Prof., Dept. of Architecture, Fac. of Sci. \& Eng., Toyo University, Dr.Eng.
}

When existing buildings are reinforced against earthquakes, concrete roughened through chipping (herein simply referred to as "roughened concrete") and post-installed anchors are often used to join reinforcing parts, such as steel braces and vibration control braces, to the structures. Roughened concrete increases the rigidity of the interlocking resistance and bearing resistance, and it can also increase the shear strength.

The authors have proposed the use of cylindrical shear-keys in place of roughened concrete as a joining technique. This combination of a cylindrical shear-key and a post-installed anchor is expected to reduce the shear displacement at the joint surface and increase the shear strength. However, when these techniques are used in combination, the stress state of the joint is complex, and the mechanical behavior of the cylindrical shear-keys and post-installed anchors are different. Therefore, it is necessary to verify whether the combination can be evaluated using a mechanical model that adds the mechanical model of each technique (herein termed "pre-modified model"). The purpose of this study is to perform shearing tests with a test specimen composed of a cylindrical shear-key and a post-installed anchor used in combination, to estimate the axial stress state at the joint from the test results, and to propose a mechanical model for the combination (herein termed "modified model") reflecting these effects.

The test results showed that when a post-installed anchor and a cylindrical shear-key were used in combination, the value of the aperture displacement $\delta_{V}$ exceeded the value of $\delta_{V}$ when a single post-installed anchor was utilized. Therefore, because the axial force $T$ at the anchor bolt increased when used in combination, we observed a tendency for the bending moment $M$ to decrease. From these test results, the shearing force $C_{\delta} Q_{a}$ resisted by the post-installed anchor when used in combination was estimated to be approximately 0.7 times the value when a single post-installed anchor was used. Furthermore, as the average compressive stress ${ }_{a} \sigma_{0}$ at the joint surface added by the vertical component of $T$ had an average value of $-0.60 \mathrm{~N} / \mathrm{mm}^{2}$, this axial stress should be considered in the mechanical model of the cylindrical shear-key when used in combination. The shearing force transmitted by the cylindrical shear-key when used in combination could have increased owing to these reasons. Furthermore, considering that the mechanical behavior of the cylindrical shear-key was exhibited in the gradually increasing load region until the anchor bolt yielded when used in combination, the shear displacement, $\delta_{\max }$, was $0.63 \mathrm{~mm}$ when it reached the shear strength based on the mechanical model of the cylindrical shear-key. The average value of $\delta_{H}$ when the anchor bolt reached its yield, resulted in a value exceeding $\delta_{\operatorname{maxl}}=0.2 \mathrm{~mm}$ when a single anchor bolt was used.

In this study, we performed a detailed examination, focusing on the stress state at the joint when a post-installed anchor and a cylindrical shear-key were used in combination. We have shown that the modified model can be used to predict experimental values at higher accuracy, compared with the pre-modified model. 